\title{
A Strategic Study on the Development of Financial Technology for Small and Medium-sized Commercial Banks-sample Analysis Based on the City's Business Community
}

\author{
Xiaoming Qiao \\ Journal Editorial Department, Yunnan Normal University, Kunming, 650092, China
}

Keywords: Urban commercial banks, Financial technology, Big data, Cloud computing, Block chain, Artificial intelligence

\begin{abstract}
Urban commercial banks are an important part of China's financial system. It plays an important role in supporting small and medium-sized enterprises, promoting the construction of inclusive financial system and practicing the national macro strategy. General Secretary Xi Jinping stressed the need to further support the development of urban commercial banks at the national financial work conference held in July. This means that the innovation and development of urban commercial banks have risen to the national strategic level. In recent years, although the urban commercial banks develop rapidly, compared with the large-scale commercial bank, the disparity still has the unceasing expansion tendency. In addition, the urban commercial bank's internal differentiation rate is also further enhanced. The rapid development of financial technology has become a precious opportunity in the financial field. It is not only the source of this differentiation, but also the means to narrow the gap. Therefore, it is necessary to analyze the development of urban commercial banks and explore their coupling with finance technology and research how urban commercial banks to develop their own core competitiveness in the development of financial technology. In the face of financial technology, urban commercial banks should grasp the opportunity in the full use of their own advantages, the rapid implant technology gene, and creating "small but beautiful", "small but excellent", "small but special", "small but wisdom" of financial technology company.
\end{abstract}

\section{Introduction}

After twenty-two years of development, city commercial banks have undergone profound changes in terms of market competitiveness, social influence and business viability through a series of optimization measures such as asset restructuring, transformation and upgrading, risk mitigation and brand building. First, the city commercial bank is an important group in the Chinese banking system and the financial ecological chain [1]. Secondly, the city commercial banks play an important role in supporting the growth of small and micro enterprises and the development of Inclusive Finance. Finally, in the spirit of the national financial work conference of the Central Committee of the Communist Party of China, the support of the development of city commercial banks was emphasized again. However, at the same time the development trend of the city commercial bank is better, the problem of its unbalance of development is becoming more and more obvious [2]. On the one hand, the development of urban commercial banks and large commercial banks is differentiated. Therefore, financial science and technology is not only an innovative tool to realize the leapfrog development of the city and commercial banks, but also a key factor for the further increase of the development gap of the city commercial banks. Based on exploring the city firm financial technology strategy implementation path, to achieve turn overtaking and balanced development, in the "13th Five-Year" critical period of building an innovative country and implement the financial security of the CPC Central Committee work conference has important theoretical value and practical significance. 


\section{City Commercial Banks and Financial Technology are Natural Coupling}

\subsection{Coupling Mechanism of City Commercial Banks and Financial Technology}

The city commercial bank and the financial science and technology have the symbiotic symbiosis. Apart from the inherent shortcomings and shortcomings, the city commercial banks also have strong endogenous growth power. In the process of interaction with financial technology, city commercial banks continue to take advantage of their strengths to supplement, improve and enhance their comprehensive strength and form an advantage interaction effect [3].

\subsection{Financial Technology is to Increase the Gap between Commercial Banks}

The development of financial science and technology influence on Commercial Bank Group is the largest city commercial bank, development of financial technology to large commercial bank services in large and medium sized customers at the same time, including the long tail of customers as possible, in competition with large commercial banks, city commercial business areas deep erosion may be affected by the strength of the. The specific performance is on the scale of development, the quality of development and the benefit of development.

\subsection{Financial Science and Technology is a New Opportunity for the City Business Bank to Overtake}

The application of artificial intelligence and big data in the investment field spawned digital asset allocation, and city commercial banks make up for the short board of private banking and wealth management in retail business by reducing the cost of exhibition industry. Block chain technology covers financial services such as digital money, intelligent contracts, payment clearing and settlement, and is changing the rules of the whole financial industry. Financial technology is a technology driven financial innovation. It follows the essence of finance, and based on data and technology, changes the channels of financial services, improves the efficiency of financial system and reduces the cost of financial services [4].

\section{Analysis on the Weakness of the Development of Financial Science and Technology of City Commercial Banks}

Compared with the large commercial banks, city commercial banks financial technology advantage is more flexible, can better avoid the problem; but the leadership rendered ineffectual by recalcitrant subordinates "because the city firm profitability, personnel system, resource endowment and other factors, the development of financial technology still faces many difficulties.

\subsection{Lack of Massive Data Support}

The development of financial science and technology requires massive original and effective data support. However, the city commercial banks have many disadvantages in the data accumulation. Because of the small number of customers, the business system is thin and its data precipitation and data collection ability is relatively deficient.

\subsection{Lack of "Technology + Finance" Type of High-end Compound Talents}

Financial technology competition is essentially a contest of high-end financial talents. Large commercial banks have occupied the heights of scientific and technological talents by means of platform, resources and investment.

\subsection{Serious Shortage of Investment in Scientific Research}

On the one hand, the research investment awareness of city commercial banks is not strong. According to incomplete statistics, the R \& D investment of city commercial banks is only $3 \%$ of the total revenue, while Internet Co accounts for about $25 \%$. On the other hand, the huge investment of city commercial banks difficult to bear alone financial development and application of science and 
technology, the city firm profitability is limited, the huge investment in science and technology will become the heavy burden of city commercial banks. Objectively speaking, in the "armament" competition of financial science and technology, the city commercial bank is unable to undertake huge investment, and the probability of independent development of scientific and technological platform is extremely low.

\subsection{Cannot to "Stand on the Shoulders of Giants" to Develop Science and Technology}

As of now, the four major state-owned banks in industry, agriculture, in construction as the representative in the field of science and technology and financial expansion "of strategic cooperation", large commercial banks will make full use of the advantages of Internet Co, financial technology development will be into the fast lane. And out of "cost-benefit" constraints, large Internet Co tend to large commercial banks and Internet Co cooperation, cooperation of city commercial banks only with relatively poor strength, technological development ability, products of poor stability, the city firm financial needs cannot be met, the development of science and technology will therefore encounter bottlenecks.

\subsection{Lack of Ability to Build Financial Science and Technology Platform}

On the one hand, due to the rapid change of financial technology, the technology of city commercial banks is often subject to service providers. Compared with the rapid development of private banks in recent years, city commercial banks do not have the technology gene and application scenarios of private banks, on the other hand, City commercial institutions are often subject to old ideas, scientific and technological strength is weak, less capital accumulation and other factors, limiting their own development of science and technology innovation ability, part of the city commercial management innovation project insisted that there must be a "predictable, and can be recognized by the results, missed the best time of $\mathrm{R} \& \mathrm{D}$ investment or technological innovation cooperation with other organizations.

\section{Strategy Implementation Path of Financial Science and Technology of City Commercial Bank}

\subsection{Develop Strategy Development}

The city firm for the future direction of development of the industry must have forward-looking consciousness, not only need to recognize its and large commercial banks to compete, but also with the P2P network lending, mobile payment represented by new financial formats for market share of commercial banks, as the information and technology intensive industries, the development of Science and technology will be an important path to financial it can occupy a space for one person in the future market competition. Therefore, city commercial banks should combine their own advantages and resources, as soon as possible to develop the information system architecture, network development mode, customer demand level, business methods and operating cost efficiency and other aspects of the financial development strategy of science and technology, improve the development of science and technology in the importance of financial management in the frame of city commercial banks.

\subsection{Fix Scientific Position}

City commercial banks should address the gap, to avoid direct competition with large commercial banks, management dislocation competition and strategic choice of city commercial banks differences in financial development of science and technology, because of the financial needs diversification, there may not be a mechanism can meet the diversified and multi-level financial services in the world. First, the city firm need to tap the blank field of financial market, and develop characteristic and differentiation, which cannot replace the business model to fill the gaps in the field; second, city commercial banks should according to its own characteristics, formation and their ability 
to adapt to the development of science and technology resources and financial model; third, although the capital city firm with the strength of large commercial banks compared to the gap between the obvious, but its local social recognition is generally higher than the large commercial banks, city commercial banks should therefore continue to cultivate the local financial services market segmentation, the use of home advantage will be applied to all financial technology scene.

\subsection{Implant Science and Technology Elements}

City commercial banks are committed to implanting technology elements into the banking business framework. Banks should extensively apply financial and technological means in order to achieve precise financial marketing, intelligent financial management and efficient risk control. Due to the relatively limited profitability of the city commercial banks and the high cost of self-built financial and technological platforms, the city commercial banks should choose the strategy of "ship to sea" to improve their financial technology level, and strive to engage in cross-border cooperation with financial technology service companies. First, referring to the development of science and technology financial mode of large commercial banks, taking advantage of the technology of Internet financial enterprises and advanced concepts to develop its own financial technology; second, from CITIC Bank and Baidu jointly established by science and technology as the main characteristics of Bailing bank model, and through the Internet technology company holding way to implant financial technology gene; third. From the merchants bank and Jindong to set up independent legal direct bank, to create their own brand products with the core technology of Internet financial company. The city business bank should actively invest in this open financial ecological environment, share the results, develop and grow.

\subsection{Strengthen Science and Technology Applications}

Wide application of financial technology in commercial banking industry has become an irresistible historical trend, the city firm in the shortest possible time to make up for the short board, enjoy their technology dividends, reduce operating costs, which requires the city commercial banks in their business all the key used widely with large data, cloud computing, block chain and artificial intelligence technology as the representative of the financial. First, city commercial banks can use data visualization technology, massive data intelligence processing technology and other big data technology to grasp the specific preferences of users, analyze customer behavior, and achieve targeted marketing and precise marketing, at the same time, it can also reduce the risk level of banks. Second, cloud computing technology can improve the security of the retail business system of urban commercial banks and reduce the cost of system construction by improving the expansion of internal IT resources. Third, city commercial banks can use AI to finish intelligent customer service, product design, front-end information acquisition, intelligent payment and other businesses, which can improve the efficiency of commercial banks' retail business while optimizing user experience. Fourth, city commercial banks can improve the retail trading system and other systems with the advantage of "de centralization" of the block chain, and establish the trust mechanism of the retail business of the city commercial banks and ensure the authenticity of the information.

\subsection{Strengthen Science and Technology Innovation}

Technological innovation can introduce new combination of production factors and production conditions to the production system and the way to solve a series of problems in the development of the industry at the same time limit can provide continuous power and balanced for the industry connotation development, so the city firm want to turn overtaking must rise to financial technology innovation development strategy level.

\subsection{Cultivate Science and Technology Talents}

The shortage of scientific and technological personnel is an important short board for small and medium-sized businesses to develop financial and technological strategy. It is reported that, according to the average standard of domestic commercial banks, the loss rate of science and technology 
personnel in city commercial banks is generally higher than $50 \%$. Financial technology need to have business skills, IT skills, mathematical skills comprehensive and professional talent, high-end complex financial talents from culture to work requires a longer learning period, so to grasp the future development trend of bank, the distribution of talent. First, city commercial banks should actively cooperate with famous universities and professional Internet Technology Company, and establish a joint financial and technological laboratory, to build a platform for urban business talents to rapidly improve financial and technological capabilities. Second, the city business bank should excavate its own scientific and technological strength and set up a financial science and technology team. City firms can use their own resource endowments, carry out business and study financial technology at the same time, and improve their scientific and technological teams in a certain range of trial and error. Third, we should adopt certain incentive mechanism to introduce mature talents in mathematics, statistics, communication and so on.

\subsection{Prevent Financial Science and Technology Risks}

As the cornerstone of our financial market, the steady development of commercial banks is the first prerequisite for the guarantee of the banking industry. Financial technology in improving the efficiency of bank service and reduce the cost of banking services, the optimization model of banking services at the same time, but also because of the risk of breaking the limit of time and space, the rapid dissemination of information, information technology dependent magnifies the banking industry, so the city firm to use in the prevention of financial risks under the premise of financial technology innovation. First, city commercial banks should establish digital financial and technological supervision system. The development of financial technology depends on the support of digital information technology. Therefore, the prevention and control of risks should also be realized by means of technology. Second, establish the internal control system for the risk prevention of financial science and technology. City commercial banks should establish strict internal control system, strengthen the behavior standardization and mutual supervision of posts in financial and technological fields, guard against financial and technological risks at the institutional level, and third, strengthen risk prevention and control consciousness of financial scientists and technicians. City commercial banks should select financial science and technology talents according to standards and procedures, and strengthen the risk prevention and control consciousness of financial scientific and technological personnel through relevant post tenure audit system and outgoing audit system.

\section{Conclusions}

City Commercial Bank is an important part of China's banking industry and even the whole financial market. It is also an indispensable part of China's financial ecological chain. However, at the present stage, the three dimensional differentiation between the city commercial banks and the large commercial banks and the urban commercial banks has formed the trend of "three dimensional differentiation". There is natural coupling between city commercial banks and financial technology. Financial technology is not only the reason for forming this differentiation, but also the new opportunity for city commercial banks to overtake corners. Therefore, city commercial banks should be formulated in accordance with the scientific development strategy and business positioning, implant technology elements, strengthen the application of science and technology, strengthening scientific and technological innovation, talent cultivation, prevention of financial risk of science and technology to build seven path "small is beautiful", "small but excellent" small "and" small and special "wisdom" of financial technology company in order to achieve leapfrog development at the same time enjoy the technology dividend.

\section{References}

[1] Chen Yihong. Challenges and Opportunities under the New Normal-2014 Annual Review of City Commercial Banks [J]. Journal of Financial Development Research, 2015(6): 73-79. 
[2] Lu Minfeng. Discussion on the Path Selection of the Transformat ion and Upgrading of Chinese City Commercial Banks [J]. 2016(5): 112-131.

[3] Wang Renxiang, Yang Man. The Coupling elationship between Technology Innovation and Financial Innovation and Its Effects on Economic Efficiency-Based on Panel Data from 35 Countries [J]. Soft Science, 2015, 29(1): 33-41.

[4] Lu Minfeng, Yu Pengfei. Trends of Fin-Tech and Commercial Bank's Innovative Development [J]. The Chinese Banker, 2017(4): 127-130. 